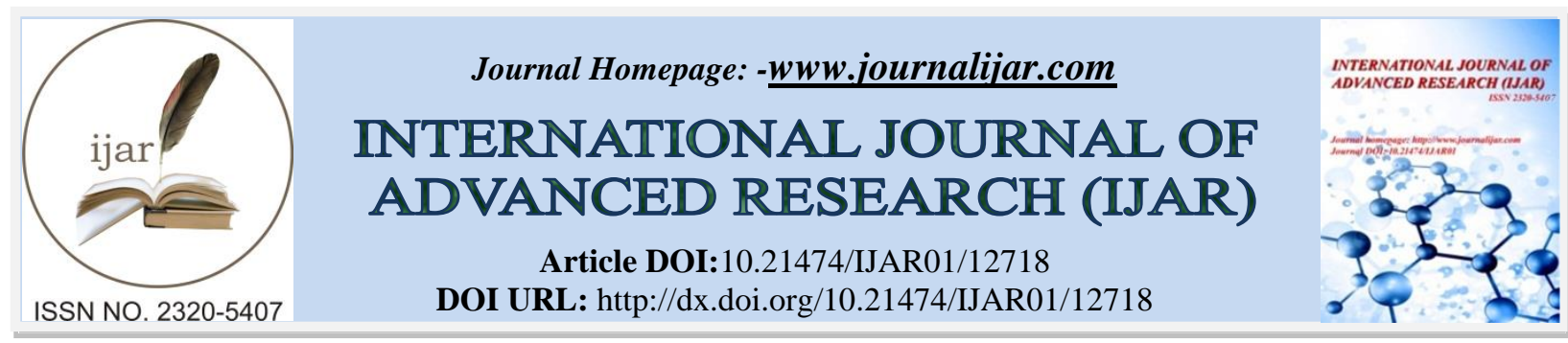

RESEARCH ARTICLE

\title{
ENGLISH PROFICIENCY AS A PREDICTOR OF EFFECTIVE CLASSROOM COMMUNICATION: A CASE STUDY OF TERTIARY INSTITUTIONS IN NORTH CENTRAL NIGERIA
}

1. Department of English.

\author{
Muhammad-Badar S. Jibrin ${ }^{1}$ and Thomas Adubika ${ }^{2}$
}

2. Department of Library and Information Science, Kogi State College of Education, Ankpa.

\section{Manuscript Info}

..........................

Manuscript History

Received: 10 February 2021

Final Accepted: 16 March 2021

Published: April 2021

Key words: -

English Proficiency, Undergraduates,

Classroom Communication

\section{Abstract}

The purpose of this present study was to determine the predictive role of English proficiency on effective classroom communication using undergraduates from tertiary institutions in the North Central of Nigeria. Two hundred and thirty undergraduates $(n=230)$ were randomly selected from Kogi and Benue states as the participants. Data for the study was collected using a self-report instrument measuring English proficiency and classroom communication as operationalized in the study. Linear regression analysis was conducted on the data, and the result showed that English proficiency statistically significantly predicted classroom communication. The study concludes that English proficiency is a determinant of student-teacher classroom interaction. The practical implications are discussed.

Copy Right, IJAR, 2021, All rights reserved.

\section{Introduction: -}

The English language is the official language in Nigeria (Mercy, 2019). It is a ubiquitous part of teaching and learning in the educational sector and beyond. In Nigeria, the absence of a national unifying indigenous language has led to the English language's adoption as a medium of intra-national and inter-national communication (Fakeye 2006). More importantly, English has become the spindle on which the educational wheel of Nigeria rotates. English functions as the language of education, instruction, educational evaluation, the media, government, politics, law, and legal documents in Nigeria (Adebileje \& Akinola, 2020). English is the vehicle of interaction and an instrument of communication (Abubaka, 2018). The language is the standard of instruction for all school subjects from the daycare to the tertiary level and a compulsory school subject that must be passed at all levels of education in Nigeria. The teaching and learning of English are essential for Nigerian students (Mercy, 2019). It has also become the medium of social interaction in every sphere of our socio-world.

Effective communication is so central and indispensable in the classroom teaching and learning process (Fashiku, 2017; Ismail \& Idris, 2009).Classroom instructors are expected to communicate effectively and convey accurately for learning to occur. Hence, teacher's effectiveness is determined by how they communicate with the students (Brown, 2005). However, feedback from the learners through proper communication is essential in indicating learning and possible clarifications. Therefore, classroom communication can be explained as a student and teacher interaction in a learning environment in the simplest term. Consequently, if there is a breakdown in communication in the classroom, teaching and learning will be affected negatively. Indeed, teachers are experiencing difficulty achieving effective communication in the classroom to achieve an efficient teaching-learning process (Cegarra \& María, 2020). 
In the classroom, effective communication remains the highest challenge to teachers at the undergraduate level in this 21 st century(Subha \& Nagarani, 2009). Meanwhile, it is the veritable tool and bedrock upon which the teachers' indispensable and significant roles are made. It enhances complete and expressive interaction between the teachers and the learners. For instance, studies have found a high and positive relationship between teacher's effective communication in the classroom and students' motivation in learning (Akudo, 2020). It is also crucial for the presentation of a lesson or lecture in class (Das, 2014). However, effective communication has an essential function in teaching because failure in communication will result in an unsuccessful process (Mahmud, 2017). Possibly, problems and failures associated with classroom performance could be attributed to ineffective communication in the classroom. Positive teaching and learning can only take place when there is effective communication in the classroom(Chung et al., 2016; Duta et al., 2015; Trihastuti \& Zamzani, 2018)

Proficiency is operationalized in this study as a student's ability to effectively use English to communicate meaning in spoken and written contexts while adhering to the basic principles of grammar. English proficiency is an essential indicator of success in academics. Research suggests that teachers' general proficiency significantly affects how they use language in the classroom to promote learning (van Canh \& Renandya, 2017). At the same time, proficiency in English is used as a measure of student's competency in Nigerian schools(Ghani et al., 2012). Therefore, students are expected to read, write, listen and speak effectively for proper teaching and learning.

Previous studies have established a link between English proficiency and academic performance in Nigerian samples (e.g., Dogo, 2016; Fakeye \& Ogunsiji, 2009; Jimoh \& Kenneth, 2016; Oyinloye et al., 2020; Taiwo, 2018; Ozowuba, 2018). For instance, Fakeye and Ogunsiji (2009) studied English proficiency as a predictor of academic achievement among students in Nigeria and their findings showed that the English proficiency has a significant positive relationship with student's overall academic achievement and there is a significant impact of the English language proficiency on student's overall academic achievement. The result is congruent with several findings in different parts of the world (e.g., Maleki \& Zangani, 2007;Feast, 2002; Bayliss \& Raymond, 2004), indicating that students can be disadvantaged in their academic performance due to low proficiency in English. Indeed, most students and graduates in Nigeria connotes standard English in their formal and informal discourse (Ghani et al., 2012).

\section{The present study}

The importance of student-teacher communication in the classroom has been established(Jafari \& Asgari, 2020; Rawat, 2016; Tan et al., 2019; Asrar et al., 2018). For the purpose of the current study, we refer to effective classroom communication as the ability of the student to effectively interact with the teacher and express one's position in the learning process. Thus, communication relating to questions, reporting incomprehension, and demanding clarity. Observation of classroom interaction between teachers and students suggests that most students are left out in the process of teaching due basically to the inability to use English effectively. The fear of uttering blunder, the embarrassment accompanying wrong grammar, the psychological mechanisms of stage fright, and the influence of mother tongue mostly restrict some students from participating in classroom activities. Nevertheless, we assume that the trend is pervasive among the undergraduates. This study investigates English language proficiency as a scarcely explored factor predicting effective classroom communication among students in Tertiary institutions in North Central Nigeria. The current study's main objective is to investigate English language proficiency as a predictor of classroom communication.

\section{Hypothesis}

It is hypothesized in this present study that English language proficiency will significantly predict classroom communication among undergraduates.

\section{Method: -}

The present study adopted a cross-sectional survey design. Students from Tertiary Institutions in the North Central Region of Nigeria constituted the research population. A total of two hundred and thirty $(n=230)$ students within the age range of 20-40 years comprising male and female were randomly selected from a public tertiary institution in Kogi and Benue States of Nigeria. 


\section{Measures: -}

\section{English language proficiency}

English language proficiency was measured with a scale designed to assess the level of one's English-speaking proficiency. The scale was adopted from the English Language Proficiency Test (ELPT), is the standardized TOEFL Paper Test and Interview designed to test the individual's speaking skills, and the International English Language Testing System (IELTS) designed to measure English language proficiency more generally in everyday situations. A higher score on this scale indicates a higher proficiency level. The instrument was validated following a pilot study, and .87 Cronbach's alpha was obtained.

\section{Classroom communication}

Classroom communication was measured using an instrument designed to measure student's ability to communicate, ask questions and express satisfaction in the classroom. The scale consists of 10 items in a 5-points Linkert-type. The instrument contains questions such as "My English is very poor" "I don't like asking questions in class. "A lower score indicates high classroom communication skills. In this study, Cronbach's alpha .88 was recorded for the instrument following a pilot study.

\section{Procedure}

With the aid of research assistants, students from three different tertiary institutions were recruited for the study. The participants were mainly pooled from the student's lodges and classrooms. A total of 265 students were approached and asked to participate in a study to gain a better understanding of their English proficiency and how it affects them in the class. In all, 251 students out of the 265 approached agreed to participate in the study. Hence, the instruments were administered to them. Two hundred and fifty-one (251) copies of the scale administered were completed and retrieved on the spot. Nevertheless, only the satisfactorily filled questionnaires (i.e., 230) were used for the study.

\section{Result: -}

Table 1: - Table showing the result of the simple regression analysis conducted to examine English proficiency as a predictor of classroom communication.

\begin{tabular}{lcccccccc}
\hline & & \multicolumn{2}{c}{$95 \%$ CI for B } & & & & & \\
\cline { 3 - 5 } & B & LL & UL & SEB & $\beta$ & $R^{2}$ & $\mathrm{t}$ & Sig \\
\hline Model & & & & & & & & \\
Constant & 1.849 & 1.785 & 1.913 & .033 & & & 56.699 & .000 \\
CC & -.739 & -.826 & -.652 & .044 & -.740 & .548 & -16.726 & .000
\end{tabular}

Note. $\mathrm{CC}=$ Classroom communication; $\mathrm{B}=$ Unstandardized regression coefficient; $\mathrm{CI}=$ Confident Interval; $\mathrm{LL}=$ Lower Limit; UL $=$ Upper Limit; $\mathrm{SEB}=$ Standardized error of the coefficient; $\beta=$ Standardized coefficient; $\mathrm{R}^{2}=$ Coefficient of determination. ${ }^{*} \mathrm{P}<.000$.

A simple regression analysis was conducted to determine the predictive role of English language proficiency on classroom communication. The analysis showed that English language proficiency statistically significantly predicted the participant's ability to communicate effectively in the classroom at $\mathrm{F}(1,228), 279.754, \mathrm{P}<.000$. Thus, our assumption that English proficiency will significantly predict classroom communication was supported.

\section{Discussion: -}

The current study focused on the predictive role of English proficiency on effective classroom communication among students in tertiary institutions. The simple regression analysis conducted on the data showed that English proficiency statistically predicted effective classroom communication. The finding indicates that students' proficiency levels in English are a determinant of their participation in the classroom and have broader implications in academic performance. The finding can be explained in line with the notion that intermittent use of English negatively impacts English proficiency. Similarly, (Ozowuba 2018; Susanti, 2016) stated that English speaking in the northern geopolitical zone of Nigeria is mostly restricted to the classrooms. Consequently, the students find no 
reason to use the language outside the classroom except when in contact with non-indigenes. The finding is consistent with previous studies (Asif et al., 2018). For instance, (Otto, 2018), found that English proficiency prevented Pakistan students from speaking in the classrooms.

Furthermore, the finding implicates English proficiency in the observed low student classroom participation among students in Nigeria. Poor vocabulary inhibits learner's maximum participation in class activities (Agbatogun, 2012). Similarly, Agbatogun (2012) opined that student's communicative competence positively and significantly correlated with listening and speaking skills. For learning to occur among the students in the classroom, the students must have a clear interpretation of the teacher's teaching. However, understanding what the teacher is teaching entails listening, asking questions, and useful feedback. This study suggests that teachers should create an inclusive opportunity to accommodate the low proficient students

\section{Limitations, strengths, and future directions}

Caution is advised in generalizing this study's finding due to the observed limitation it encountered that needed to be reported. For example, the sample size, comprising only students from tertiary institutions in two states, posed a limitation to the current study's generalizability. The data used for the study was exclusively based on self-report, which could raise the issue of common method variance. However, the current study contributes to the English literature by finding proficiency as an essential variable in classroom communication, therefore, expanding our knowledge of the causes of lowstudent-teacher classroom interaction among undergraduates in the North-Central of Nigeria. Moreover, to the best of our knowledge, research attempting to investigate the relationship between English proficiency and classroom communication using Nigerian samples is scarce. Hence, justifying our study. Future studies should consider the use of data from more inclusive sources and endeavor to utilize data triangulation.

\section{Practical implication}

To our understanding, the finding has provided evidence supporting the predictive effect of English proficiency in students' willingness to communicate and interact in the classroom. Also, the study is useful in providing relevant data to the education administrators and relevant stakeholders interested in promoting teachers-students classroom communication, as well as researchers as the result provides insight into the reason for poor academic outcomes among students in the North-Central region of the country.

\section{Conclusion:-}

The current study is concerned with the predictive role of English proficiency on classroom communication among undergraduates.Indeed, our expectation was confirmed by the result of the simple linear regression conducted on the data. Thus, the study concluded that English proficiency among undergraduates in Nigeria's north central regionis a crucial determinant ofstudent-teacher classroom interaction. However, it is unclear if teacher's factor contributed to the current revelation. It is recommended that teachers establish a robust, inclusive classroom that accommodates students with English proficiency concerns. Future research should also expand the representative sample to include the teachers and determine gender differences in English proficiency-classroom communication relations.

\section{Ethical considerations}

We tried to comply with the ethics of research in the process of the current study. The respondents were made to understand the study's objectives fully, and they were also reminded that participation is voluntary. Thus, they were advised to withdraw from the study at their wish. Indeed, their privacy was respected.

\section{Funding}

The present study was funded by the Tertiary Education Trust Fund (TetFund)

\section{Reference: -}

1. Abubakar Muhammad, H. (2018). Teaching and Learning English Language in Nigerian Schools: Importance and Challenges. Teacher Education and Curriculum Studies, 3(1). https://doi.org/10.11648/j.tecs.20180301.13

2. Adebileje, A., \& Akinola, A. (2020). Teaching and Learning English as a Second Language in Nigeria: Examining Evolving Approaches and Methods. Theory and Practice in Language Studies, 10(9). https://doi.org/10.17507/tpls.1009.02 
3. Agbatogun, A. O. (2012). Exploring the efficacy of student response system in a sub-Saharan African country: A sociocultural perspective. Journal of Information Technology Education: Research, 11(1). https://doi.org/10.28945/1715

4. Akudo, F. U. (2020). Relationship between teachers' effective communication and students' motivation in learning in secondary schools in Anambra state. International Journal of Scientific and Technology Research, 9(4).

5. Asif, S., Bashir, R., \& Zafar, S. (2018). What Are the Factors Affecting the Use of English Language in English-only Classrooms: Student's Perspectives in Pakistan? English Language Teaching, 11(6), 67-79. https://doi.org/10.5539/elt.v11n6p67

6. Bayliss, D., \& Raymond, P. M. (2004). The link between academic success and L2 proficiency in the context of two professional programs. The Canadian Modern Language Review, 61(1), 29-51.

7. Brown, D. F. (2005). The Significance of Congruent Communication in Effective Classroom Management. The Clearing House: A Journal of Educational Strategies, Issues and Ideas, 79(1). https://doi.org/10.3200/tchs.79.1.12-15

8. Chung, Y., Yoo, J., Kim, S. W., Lee, H., \& Zeidler, D. L. (2016). Enhancing students' communication skills in the science classroom through socio-scientific issues. International Journal of Science and Mathematics Education, 14(1). https://doi.org/10.1007/s10763-014-9557-6

9. Das, K. (2014). Kabita Das. Need of Effective Communication Skills in Teaching Science in Classroom Situation. Inter. J. Edu. Res. Technol, 5.

10. Dogo, P. (2016). Effects of English Language on Students' Performance in Teaching and Learning of Mathematical Modelling at Junior Secondary School Level in Bauchi State, Nigeria. Kenyata University Institutional Repository. Https://Ir-Library.Ku.Ac.Ke/Bitstream/Handle/123456789/17947.

11. Duta, N., Panisoara, G., \&Panisoara, I.-O. (2015). The Effective Communication in Teaching. Diagnostic Study Regarding the Academic Learning Motivation to Students. Procedia - Social and Behavioral Sciences, 186. https://doi.org/10.1016/j.sbspro.2015.04.064

12. Fakeye, D., \& Ogunsiji, Y. (2009). English Language Proficiency as a Predictor of Academic Achievement among EFL Students in Nigeria. European Journal of Scientific Research. European Journal of Scientific Research ,37, 490-495.

13. Fashiku, C. O. (2017). Effective Communication: Any Role in Classroom Teaching-Learning Process in Nigerian Schools? Bulgarian Journal of Science and Education Policy (BJSEP), 11(1).

14. Feast, V. (2002). The impact of IELTS scores on performance at university. International Education Journal, $3(4), 70-85$.

15. Ghani, C. A. A., Ataman, M. L., \& Egele, A. F. (2012). The sociolinguistic drawbacks in the English learning environment in a multilingual society. Theory and Practice in Language Studies, 2(2). https://doi.org/10.4304/tpls.2.2.319-325

16. Jafari, S., \& Asgari, A. (2020). Predicting students' academic achievement based on the classroom climate, mediating role of teacher-student interaction and academic motivation. Integration of Education, 24(1). https://doi.org/10.15507/1991-9468.098.024.202001.062-074

17. Jimoh, R., \& Kenneth, I. N. N. (2016). Effect of English Language proficiency on students' performance in cataloguing and classification courses in polytechnic - based library schools in Nigeria. International Journal of Library and Information Science, 8(6). https://doi.org/10.5897/ijlis2016.0708

18. Mahmud, M. (2017). Communicative styles of English students at the State University of Makassar. GEMA Online Journal of Language Studies, 17(1). https://doi.org/10.17576/gema-2017-1701-13

19. Maleki, A., \& Zangani, E. (2007). A survey on the relationship between English language proficiency and the academic achievement of Iranian EFL students. Asian EFL Journal, 9(1), 86-96.

20. Mercy, N. O. (2019). Challenges Facing Teaching and Learning of English Language in Public Secondary Schools in Enugu State Nigeria. Asian Journal of Education and Social Studies. https://doi.org/10.9734/ajess/2019/v4i230117

21. Ismail, N., \& Idris, K.N. (2009). The Effects of Classroom Communication on Students? Academic Performance at The International Islamic University Malaysia (IIUM). UniTAR E-Journal, 5(1).

22. Otto, A. (2018). Improving the Communication Skill of Student in Nigeria for Effective Classroom Functioning: A Counselling Perspective. In International Journal of Religious and Cultural Practice (Vol. 4, Issue 1). www.iiardpub.org

23. Oyinloye, C. A., Adeoye, A., Fatimayin, F., Osikomaiya, M. O., \& Fatola, O. L. (2020). The impact of English language proficiency testing on the pronunciation performance of undergraduates in South-West, Nigeria. Educational Research and Reviews, 15(9). https://doi.org/10.5897/err2020.4016 
24. Ozowuba, U. G. (2018). Relationship Between English Proficiency and Academic Achievement of Nigerian Secondary School Students. https://scholarworks.waldenu.edu/dissertations

25. Pozuelo. Cegarra, \& José. María. (2020). Education and new communicative methodologies: Flipped Classroom. In Signa (Vol. 29). https://doi.org/10.5944/SIGNA.VOL29.2020.23421

26. Rawat, D. (2016). Importance of Communication in Teaching Learning Process (Vol. 4, Issue 26). www.srjis.com

27. Subha, M., \& Nagarani, D. (2009). Classroom Communication in Engineering and Arts at Undergraduate Level in Indian Context. International Journal of Recent Technology and Engineering, 8(4).

28. Susanti, R. (2016). Student's perceptions towards the effective feedback practices in the large EFL writing class based on student's English proficiency level. Journal of Advances in Linguistics, 6(3). https://doi.org/10.24297/jal.v6i3.4673

29. Taiwo, F. O. (2018). Is Attitude an Impediment to Achieving English Proficiency amongst the Final Year Students in the Northern Geopolitical Zone of Nigeria: A Comparative Study of Southern and Northern Geopolitical Zones. Frontiers in Education Technology, 1(1). https://doi.org/10.22158/fet.v1n1p24

30. Tan, Y. J., Quek, C. L. G., \& Fulmer, G. (2019). Validation of Classroom Teacher Interaction Skills Scale. Asia-Pacific Education Researcher, 28(5). https://doi.org/10.1007/s40299-019-00444-6

31. Trihastuti, Y. A., \& Zamzani, Z. (2018). The Role of Communication Strategies in the Classroom Communication. https://doi.org/10.2991/iccsr-18.2018.65

32. Ugonna G. Ozowuba. (2018). Relationship between English proficiency and academic achievement of Nigerian secondary school students. Walden Dissertations and Doctoral Studies.

33. van Canh, L., \& Renandya, W. A. (2017). Teachers' English Proficiency and Classroom Language Use: A Conversation Analysis Study. RELC Journal, 48(1). https://doi.org/10.1177/0033688217690935

34. Zaeema Asrar, Noman Tariq, \& Hira Rashid. (2018). The Impact of Communication Between Teachers and Students: A Case Study of the Faculty of Management Sciences, University of Karachi, Pakistan. European Scientific Journal, 14(16), 32-39. 